\title{
HIV-1 RNA processing as therapeutic target: characterization of small molecule modulators of HIV-1 RNA processing and transport
}

\author{
Raymond Wong ${ }^{3}$, Ahalya Balachandran', Matthew Haaland', Peter Stoilov², Alan Cochrane ${ }^{\text {** }}$ \\ From Frontiers of Retrovirology: Complex retroviruses, retroelements and their hosts \\ Cambridge, UK. 16-18 September 2013
}

\section{Background}

Control of RNA processing plays a central role in the expression of the HIV-1 genome. From a single $9 \mathrm{~kb}$ transcript, more than 40 mRNAs are generated through suboptimal splicing, a subset of which are dependent upon the HIV-1 factor Rev for export to the cytoplasm. To identify small molecule modulators of HIV-1 RNA processing, we performed a screen to isolate compounds capable of inhibiting HIV-1 gene expression postintegration.

\section{Materials and methods}

Initial screens were performed in the HeLa rtTA HIV $\Delta$ mls cell line containing a doxycycline inducible HIV-1 provirus. Effects of compounds on HIV-1 expression were analyzed using p24 ELISA, western blots, in situ hybridization and qRT-PCR. To confirm that the responses observed were not unique to this cell line, assays were repeated in a chronically infected $\mathrm{CD} 4+$ $\mathrm{T}$ cell line (24STNLESG).

\section{Results}

Two compounds displayed significant suppression of HIV-1 gene expression; 8-azaguanine, and 2-[2-(5-nitro2-thienyl)vinyl] quinoline (5350150). Both compounds significantly reduced the production of HIV-1 Gag and Env with limited effects on Rev and Tat accumulation. While 8-azaguanine, was found to induce a significant alteration in the levels of unspliced, singly spliced and multiply spliced HIV RNAs, consistent with inducing an oversplicing phenotype, 5350150 had a more limited effect. Similar responses were seen using two distinct HIV-1 infected cell lines, suggesting that the response is conserved across multiple cell types. The lack of effect of both compounds on Rev and Tat levels while reducing expression of the HIV-1 structural proteins suggested that Rev function was being affected. Consistent with this hypothesis, both 8-azaguanine and 5350150 induced cytoplasmic accumulation of Rev suggesting an alteration in Rev's ability to shuttle between the nucleus and cytoplasm and blocked nuclear export of HIV-1 genomic RNA as measured by in situ hybridization. Parallel analyses did not detect changes in the localization of known shuttling host proteins (hnRNP A1, SRp20) and only limited alterations of host RNA alternative splicing, suggesting that HIV-1 processing is highly sensitive to the effects induced by these compounds. To validate the anti-viral activity of these compounds, their capacity to suppress replication of HIV-1 isolates in PBMCs is being evaluated.

\section{Conclusions}

Both 8-azaguanine and 5350150 impaired HIV-1 expression by altering viral RNA processing through effects at the level of RNA splicing and export. Together, our findings establish that HIV-1 RNA processing can be modulated with small molecules to suppress HIV replication, establishing a new avenue for the treatment of this infection.

\section{Authors' details \\ ${ }^{1}$ Molecular Genetics, University of Toronto, Toronto, Ontario, Canada. ${ }^{2}$ Biochemistry, West Virginia University, Morgantown, WV, USA. ${ }^{3}$ Laboratory Medicine \& Pathobiology, University of Toronto, Toronto, Ontario, Canada.}

${ }^{1}$ Molecular Genetics, University of Toronto, Toronto, Ontario, Canada

Full list of author information is available at the end of the article

(C) 2013 Wong et al; licensee BioMed Central Ltd. This is an Open Access article distributed under the terms of the Creative Commons Attribution License (http://creativecommons.org/licenses/by/2.0), which permits unrestricted use, distribution, and reproduction in any medium, provided the original work is properly cited. 

target: characterization of small molecule modulators of HIV-1 RNA processing and transport. Retrovirology 2013 10(Suppl 1):O45.

Submit your next manuscript to BioMed Central and take full advantage of:

- Convenient online submission

- Thorough peer review

- No space constraints or color figure charges

- Immediate publication on acceptance

- Inclusion in PubMed, CAS, Scopus and Google Scholar

- Research which is freely available for redistribution

Submit your manuscript at www.biomedcentral.com/submit
C Biomed Central 